\title{
Improving the quality of Internet banking services: An implementation of the quality function deployment (QFD) concept
}

\author{
Ade Maharini Adiandari ${ }^{a}$, Hendra Winata ${ }^{b}$, Mahayanti Fitriandari ${ }^{a}$ and Taqwa Hariguna ${ }^{c^{*}}$
}

${ }^{a}$ University of Ngurah Rai Denpasar, Bali, Indonesia

${ }^{b}$ University of Brawijaya, Malang, Indonesia

${ }^{c}$ Universitas Amikom Purwokerto, Indonesia

\section{H R O N I C L E \\ A B S T R A C T}

Article history:

Received: July 42019

Received in revised format: Sep-

tember 142019

Accepted: October 30, 2019

Available online:

October 30, 2019

Keywords:

Internet Banking

Quality Function Deployment

House of Quality

\begin{abstract}
The competition in the business world, including banking, is getting tighter. For that, every bank must think of the right strategy to win the competition. One important strategy for winning competition is to prioritize customer satisfaction which is determined by the quality of banking services offered to customers. This study aims to analyze and process proposals for improvement in service quality in terms of using internet banking services based on the Quality Function Deployment (QFD) method through the preparation of the House of Quality (HoQ). The study was conducted on 120 internet banking users at the BRI Balikpapan Branch Office in East Kalimantan. From the results of the analysis, it is known that there are 11 indicators of bank internet banking service quality that must be improved as the first priority and 4 indicators as the second priority. Based on the results of data processing using QFD through the preparation of HoQ, it is known that there are 6 priority improvements that must be made by the bank. From the results of this study, it can be seen strategies for improving internet banking services to improve the quality of internet banking services at the BRI Balikpapan Branch Office, namely the added of new online chat features, perform server maintenance, carry out enrolment of new internet banking features, evaluate the process speed of each application feature, conduct regular website feature evaluations every quarter and perform network repair.
\end{abstract}

\section{Introduction}

Currently the world has entered the digital era where the whole process of international integration is due to infrastructure advances, one of which is the internet. Based on data related to internet users in Asia Pacific in 2016, the highest number of Internet users is China with a number of users reaching 731.3 million, while Indonesia occupies the fourth position with the number of Internet users reaching 66.2 million (Bank, 2018). This shows that the internet has entered various aspects of life (Yuan et al., 1970). From this figure, the most accessed service is chat service with a percentage reaching $89.35 \%$, while the service that is the least accessed is banking service with a percentage only reaching $7.39 \%$. This shows the low level of internet usage for banking transaction activities in Indonesia. On the other hand, the widespread use of the internet in the practice of banking activities should be a great opportunity for banks to increase their profits through fee-based income transactions. The banking industry is one of the fastest industries in realizing developments and changes in the field of technological innovation. This is evidenced by the increasing demand for web-based banking products as a form of consumer desire to obtain banking products that are fast, effective, and productive. Electronic-based banking services (e-banking) provide an important competitive advantage for banks in terms of time, location and cost (Şanlı \& Hobikoğlu, 2015). One part of e-banking services is internet banking. Internet banking is an important component of e-banking services. It was further stated that the primary reason for the growth in internet banking services is that they reduce costs and enhance profits for banks, while enriching

\footnotetext{
* Corresponding author.

E-mail address: taqwa@amikompurwokerto.ac.id (T. Hariguna) 
customer convenience through the ease and rapidity with which transactions are executed (Stoica et al., 2015). This is consistent with research that states that internet banking helps in achieving better work efficiency and improves financial performance (DeYoung et al., 2007). Increasing competition in the banking industry causes the need to apply quality standards of services provided by banks, as well as the quality of internet banking services. Good service quality will have a positive impact on customers' perceptions of the internet banking services used. In Internet Banking, customers will interact with banks through their websites. For this, the quality of e-Servqual is vital in determining the extent to which internet banking services are offered to meet user requirements (Ariff et al., 2012). This shows that the achievement of quality in terms of service occupies a central position in the running of a business. For this reason, it is necessary to take measures and to consistently improve the quality of services, especially internet banking services, to ensure customer satisfaction is guaranteed. In this research, an analysis and processing of data quality of internet banking services will be conducted at the BRI Balikpapan branch office by using the QFD method to produce improvement proposals that can ultimately result in an improved internet banking service strategy from the BRI Balikpapan Branch Office. Furthermore, before conducting the analysis using the QFD method, it will first be carried out in an analysis using Fuzzy e-Servqual and Importance Performance Analysis (IPA). Fuzzy e-Servqual method is explained as a method used to find out the quality criteria of internet banking based on the gap between perceived and expected users, while IPA is used to determine the variables that are banking priorities.

\section{Literature Review}

\subsection{The Concept of $Q D F$}

The concept of QFD is a methodology used for product planning and development that enables companies to clearly define the wants and needs of consumers to then evaluate each product or service systematically in relation to meeting the needs of these consumers (Cohen, 1995). Whereas Sullivan (1986) states that QFD is an overall concept that provides a means of translating customer requirements into the appropriate technical requirements for each stage of product development and production (i.e., marketing strategies, planning, product design and engineering, prototype evaluation, production process development, production, sales). Furthermore Hill (1994) states that QFD evolved from a number of different initiatives between 1967 and 1972, but the two main drives which led to its creation in Japan were those to improve the quality of design and to provide manufacturing and field staff with the planned quality control chart before the initial production run (David et al., 2000). This understanding shows that QFD is not a tool, but a planning process that can be used for the benefit of consumers so that a company's product or service has good quality and highly competitive ability. This is because the proposed improvements come from consumers, directly. Regarding the initial emergence of QFD, Terninko (1997) states that in the 1960s, Quality Control and Quality Improvement had a distinctively manufacturing flavor in Japan (David et al.,2000). In the late 1960s and early 1970s, Yoji Akao and others went to work on improving the design process so that the new product was introduced to manufacturing, which was high quality from the beginning. The process for improving design was called QFD. Furthermore, the first appearance of QFD in Japan continued with the first application at the Mitsubishi Kobe Shipyards, which at that time was used to measure customer satisfaction. The emergence of QFD also occurred in the United States. For the development of QFD in the United States, Chan and Wu (1998) stated that after more than 10 years of development of QFD in Japan, Kaogure and Akao published "Quality function deployment and CQWC in Japan" in the October 1983 issue of Quality Progress, which may mark the entrance of QFD into the US (DeYoung et al., 2007). The development of the concept and use of QFD did not only occur in Japan and the United States, but began to spread to other countries. This is evidenced by the development of writings related to QFD, including in European countries (Hill, 1994; \& Herrmann et al., 2000) Germany (Herrmann et al., 2000), Singapore (Hill, 1994; Brian \& Teo, 2001) and Hong Kong (DeYoung et al., 2007; Carnevalli \& Miguel, 2017).

\subsection{The Purpose of Using $Q F D$}

In the initial stages, the development of QFD moves from two important issues that underlie its development, namely how to find ways to achieve good design quality, while the community increasingly demands the importance of design quality and the implementation of quality control by the company, which is unfortunately done after the company began to realize the existence qualities that are not what they want (Ko, 2000). In the next stage, QFD is used to ensure quality consistency that is carried out from the initial stage, that is, since the product began to be developed. This was the main objective at the beginning of the development of QFD, which was to maintain the quality of products made from the product development stage. The QFD method is considered capable of answering challenges in product research and development, so that consumer desires have been embedded into one in each stage of product development. Thus, the development of these products can be directly adjusted to the desires of the existing consumers (Lim et al., 1999). Another goal of QFD is as an effort to manage time to meet the needs of consumers, increase customer satisfaction, improve communication between parts of the company, develop documentation patterns that are much better and reduce unnecessary costs. Furthermore David et al. (2000) stated that the use of QFD for the company produced several benefits with its methods that were able to improve its quality and productivity continuously, namely focusing on consumers, time efficiency, oriented to teamwork and documentation. The benefits of QFD above can be explained as follows: first, the focusing on consumers explains that each stage in QFD activities requires input from consumers, which is then processed into a unified information as a product development process that is in accordance with consumer needs. This is done solely to improve quality for the satisfaction of consumers. Furthermore, information from 
these consumers will be compared with similar products on the market, if the product has been made by competitors, the company must be able to further deepen the research and development process in more detail. Research and development of these products is carried out by the company to better understand the capabilities of the company compared to other competing companies, primarily in meeting the needs of consumers. Second, time efficiency explains that the time needed in the product development process can be better and more efficient by implementing QFD. The main focus in developing products that are always oriented to the needs of consumers, of course, have an impact on the more effective time needed until the product reaches the hands of consumers. This can happen because the needs of consumers can be translated by the company since the early stages of product development so that the company's efforts to market products are easier, more directed more specifically according to the needs of these consumers. The process of product research and development can also be carried out focused only on product development including its features in accordance with the wishes of consumers so that it does not waste time wasting on developing products that are of less value to consumers. Third, teamwork oriented wants the involvement of the team in every decision making at the product development stage. The QFD approach which is always oriented towards teamwork can certainly occur continuously, considering the discussion process, expressing opinions and thoughts and the agreement process to achieve the objectives carried out in each stage from product development to the product is ready to be marketed. Fourth, documentation-oriented means that data obtained since the initial period of product development is done in such a way as to continuously record every product development and design that is made for future development and improvement. Every information, design changes, the results of discussions both internally and externally with consumers, as well as all decision changes are made in detail recording in accordance with the existing time frame. Thus, the continuity of changes from old information to the latest information can be read in more detail and continuously. The latest information on consumer desires is able and very effective in helping to make changes made by the company. Furthermore, if we relate to the theme of the discussion in this study, the benefits of QFD can also be felt when banks want to improve the quality of their internet banking services through the process of improving service quality using the QFD method.

\subsection{The Process of $Q F D$}

The QFD process consists of forming one or several matrices. The first stage matrix is the customer needs planning matrix or known as the HoQ. The matrix is the basis for all the matrices needed in QFD (Besterfield et al., 1999). House of Quality has 2 main parts, namely the information or input from consumers and the part that contains technical responses to respond to input from consumers. Consumer voice is the wants and needs of consumers which are the basic inputs of QFD. While entering the technical department, companies must respond to every consumer voice that enters. This technical need shows how the form of response by the company to the needs of consumers and technical needs is placed at the top of the matrix. Then the QFD team can examine and weight each information in the matrix and determine the target value for each technical characteristic. In the development of QFD, (Tan \& Pawitra, 2001) conveyed the existence of several deficiencies in QFD practice, including the voice of customers that is possible to differ between the voices of customers with one another so that there is a bias of customer opinion, it requires extraordinary effort considering the large amount of input and analysis needed in the form of subjective data. The survey carried out requires a long time and there are difficulties in carrying out input with a manual process, the possibility of the HoQ to be very large and complex, there are differences of opinion among several teams that form friction between various relationships sometimes misinterpreted, as is the case with consumers, it is possible for the implementation of QFD analysis to be imperfect and often stops at the initial HoQ so that the relationship between the four phases is not formed and the nature of QFD is often qualitative.

\section{Methodology}

This study aimed to obtain a proposal to improve the quality of internet banking services using the QFD method through the preparation of HoQ. Before conducting the analysis with the QFD method, the author will first do the analysis using Fuzzy eServqual and IPA. Fuzzy e-Servqual method is a method to find out online service quality criteria based on the gap between perceived and expected customers, while IPA is a simple tool to find out what variables are priority improvements according to customers. Furthermore, the data processing structure to achieve the research objectives can be seen in Fig. 1.

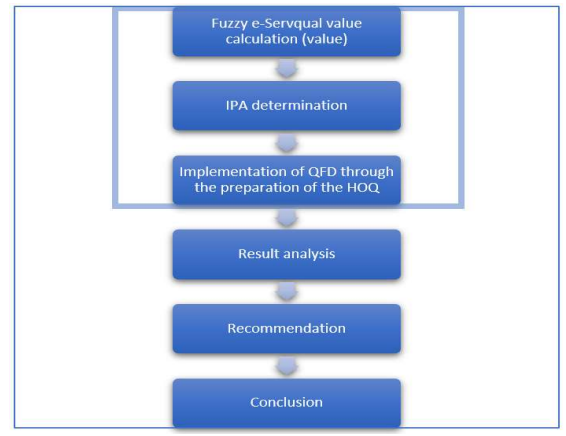

Fig. 1. Structure of Data Processing 
Fig. 1 shows the sequence of processes in processing data after the author obtained data collected through questionnaires. Furthermore, the variables and operational definitions of the variables used in this study can be seen in Table 1.

Table 1

Example table

\begin{tabular}{llll}
\hline Variable & Indicators & & \\
\hline Transaction Accuracy & Speed of transaction & Accuracy of transaction & Ease of transaction \\
Display Design & Functional display & Present appearance & Informative display \\
Ease of Access & Fast access time & Application Easy to install & Application easy to access \\
Availability of Information & Information is available as needed & Required Information Easy to obtain & Information delivered too much \\
Problem Handling & Fast problem handling & Accurate Problem handling & Easy problem handling \\
\hline
\end{tabular}

In Table 1 it can be seen that the variables in this study are 5 variables with each variable explained into 3 indicators, so the total indicators are 15. The research variables were developed from the study of Parasuraman et al. (2005) by adding one variable, namely ease of access from before 4 variables, namely transaction accuracy, display design, availability of information needed and problem handling. The sampling technique uses a purposive sampling technique with the following criteria: 1) respondents are customers of the BRI Balikpapan Branch Office and also customers of Bank BCA as BRI competitors, 2) BRI and BCA customers mentioned in point 1 have an internet banking application for each bank, 3) have used the internet banking service application as referred to point 2 at least twice in each application. The data collection method uses a questionnaire that was designed based on a questionnaire developed by (Parasuraman et al., 2005), known as e-Servqual. Furthermore, the development of the questionnaire design in this study is based on the indicators mentioned in Table 1 above. The questionnaire design consisted of 2 major sections, namely: 1) the question section related to background information and the socio-economic characteristics of the customer, 2) the section consisting of 15 statements which were grouped into 5 variables and 15 indicators.

\section{Result and Discussion}

The QFD method in this study was carried out through the preparation of HoQ. As explained earlier, before analyzing using the QFD method, analysis will be carried out using fuzzy e-Servqual and IPA. The following is presented descriptive statistics, calculation of the e-Servqual gap and the results of the preparation of "IPA". Descriptive statistics are explained in Fig. 2, the calculation of the e-Servqual gap in Table 2.

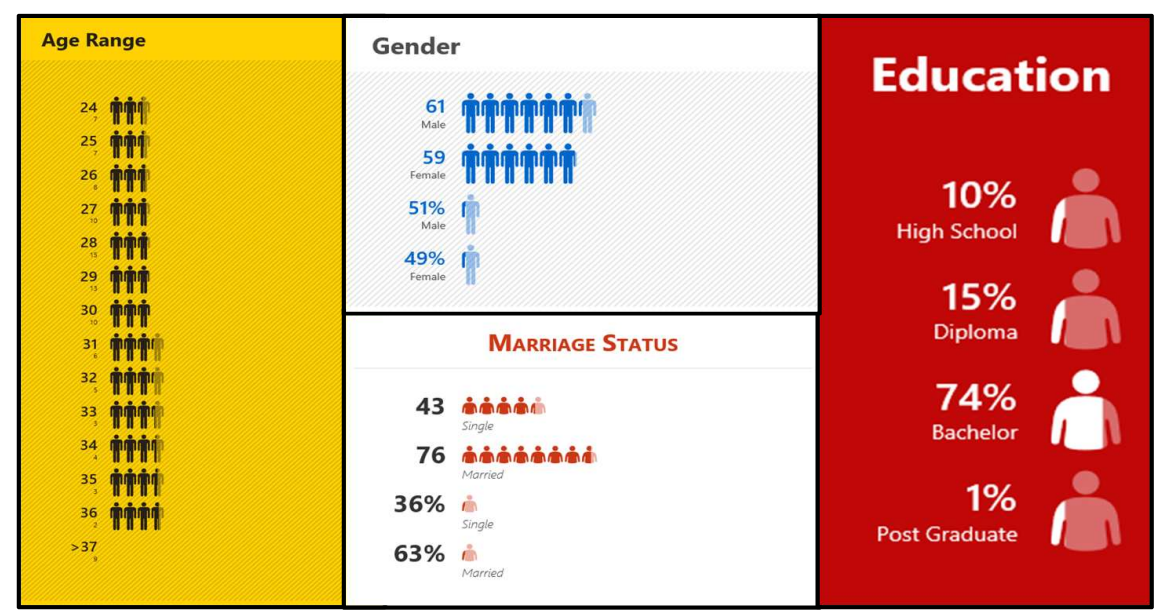

Fig. 2. Descriptive Statistic

From Table 2, it can be seen that there are negative values in all indicators. This shows there are still customer dissatisfaction with the quality of internet banking services provided by the bank. The highest dissatisfaction is seen in indicators of easy problem handling, too much information given and accurate problem handling.

Table 2

E-Servqual Gap Result

\begin{tabular}{|c|c|c|c|c|c|c|c|}
\hline Indicator & Perceived & Expected & Gap & Indicator & Perceived & Expected & Gap \\
\hline 1a (speed of transaction) & 3,42 & 3,94 & $-0,53$ & 3c (application easy to access) & 3,13 & 3,83 & $-0,71$ \\
\hline $1 \mathrm{~b}$ (accuracy of transaction) & 3,24 & 3,97 & $-0,73$ & 4a (information is available as needed) & 3,10 & 3,84 & $-0,74$ \\
\hline 1c (ease of transaction) & 3,29 & 3,84 & $-0,55$ & $4 \mathrm{~b}$ (required information easy to obtain) & 3,17 & 3,83 & $-0,67$ \\
\hline 2a (functional display) & 3,29 & 3,86 & $-0,57$ & $4 \mathrm{c}$ (information delivered to much) & 3,13 & 3,94 & $-0,81$ \\
\hline $2 \mathrm{~b}$ (present appearance) & 3,27 & 3,84 & $-0,58$ & 5a (fast problem handling) & 3,13 & 3,79 & $-0,66$ \\
\hline 2c (informative display) & 3,18 & 3,93 & $-0,75$ & $5 \mathrm{~b}$ (accurate problem handling) & 3,11 & 3,88 & $-0,78$ \\
\hline $3 \mathrm{a}$ (fast access time) & 3,14 & 3,83 & $-0,69$ & $5 \mathrm{c}$ (easy problem handling) & 3,08 & 3,94 & $-0,86$ \\
\hline 3b (application easy of install) & 3,10 & 3,85 & $-0,75$ & & & & \\
\hline
\end{tabular}




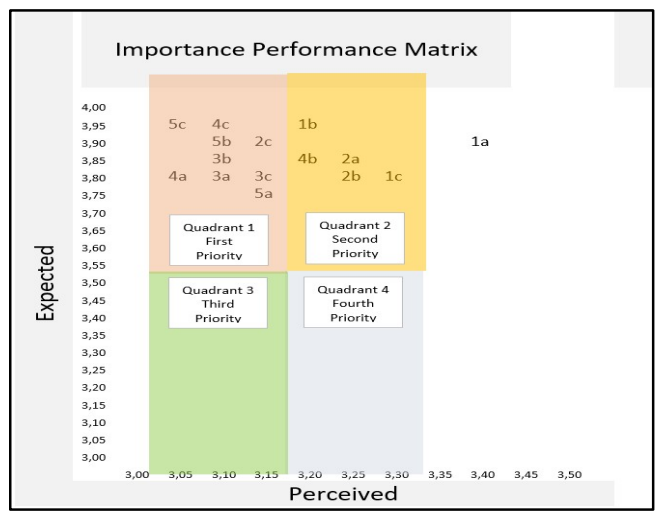

Fig. 3. Importance Performance Analysis Matrix

From the science matrix in Fig. 3 above, it can be seen that there are 11 indicators that are the bank's first priority for improvement and 4 indicators as the second priority for improvement. Then the HoQ is prepared in order to implement the QFD method to obtain proposals to improve the quality of internet banking services. As explained by (Cohen, 1995), in this study the preparation of HoQ was carried out in the following order (Cohen, 1995):

1) Voice of customer

Voice customer is a list of customer desires. The attributes included in the voice of customer can be obtained from the results of the IPA according to the Fig. 3, especially from quadrant 1. Voice of Customer is summarized in Table 3.

Table 3

Voice of Customer

\begin{tabular}{cl}
\hline No & Attribute \\
\hline $5 \mathrm{c}$ & The solution of the online transactions problems is easily done by the customer \\
\hline $\mathrm{c}$ & Too much information on the internet banking website \\
\hline $\mathrm{b}$ & Always accurate in solving problems of online transactions \\
\hline $\mathrm{c}$ & Website appearance is easy to understand \\
\hline $\mathrm{b}$ & Ease of installing applications \\
\hline $\mathrm{a}$ & Information on the internet banking website is available according to customer needs \\
\hline $\mathrm{c}$ & Internet Banking Transactions Always Accurate \\
\hline $\mathrm{a}$ & Ease of accessing applications \\
\hline $\mathrm{b}$ & Speed in accessing a website or application \\
\hline
\end{tabular}

2) Planning matrix

Planning matrix is quantitative data that shows the level of importance of the voice of customer and the level of expectation of the customer whose value has been conveyed in Table 3 . The level of importance of the voice of customer is indicated by the importance to customer (IC) value that uses the expected value in the results fuzzy e-Servqual which could be seen in Table 4.

Table 4

Importance to Customer (IC)

\begin{tabular}{|c|c|c|c|c|c|c|c|c|c|c|c|}
\hline No & $5 \mathrm{c}$ & $4 c$ & $5 b$ & $2 \mathrm{c}$ & $3 b$ & $4 a$ & $1 b$ & $3 c$ & $3 a$ & $4 b$ & $5 a$ \\
\hline Importance to Customer Value & 3.94 & 3.94 & 3.88 & 3.93 & 3.85 & 3.84 & 3.97 & 3.83 & 3.83 & 3.83 & 3.79 \\
\hline
\end{tabular}

Furthermore, the expectation level is indicated by the value of customer satisfaction performance (CSP) which uses the perceived value in the fuzzy e-Servqual results and can be seen in Table 5.

Table 5

Customer Satisfaction Performance (CSP) Value

\begin{tabular}{llll}
\hline No & Customer Satisfaction Performance Value & No & Customer Satisfaction Performance Value \\
\hline $5 \mathrm{c}$ & 3,08 & $1 \mathrm{~b}$ & 3,24 \\
$4 \mathrm{c}$ & 3,13 & $3 \mathrm{c}$ & 3,13 \\
$5 \mathrm{~b}$ & 3,11 & $3 \mathrm{a}$ & 3,14 \\
$2 \mathrm{c}$ & 3,18 & $4 \mathrm{~b}$ & 3,17 \\
$3 \mathrm{~b}$ & 3,10 & $5 \mathrm{a}$ & 3,13 \\
$4 \mathrm{a}$ & 3,10 & & \\
\hline
\end{tabular}


When comparing with other similar services, the planning matrix can compare the level of satisfaction of BRI and BCA services as competitors so that it can be seen the level of competition in meeting customer desires and this can be reflected in the value of the Goal in Table 6 .

Table 6

Goal Value

\begin{tabular}{cccccccccccc}
\hline No & $5 \mathrm{c}$ & $4 \mathrm{c}$ & $5 \mathrm{~b}$ & $2 \mathrm{c}$ & $3 \mathrm{~b}$ & $4 \mathrm{a}$ & $1 \mathrm{~b}$ & $3 \mathrm{c}$ & $3 \mathrm{a}$ & $4 \mathrm{~b}$ & $5 \mathrm{a}$ \\
\hline Goal vale & 3.90 & 3.92 & 3.88 & 3.93 & 3.92 & 3.85 & 3.83 & 3.88 & 3.91 & 3.86 & 3.89 \\
\hline
\end{tabular}

The Goal value above is obtained from benchmarking services of competitors who have greater levels of customer satisfaction. Benchmarks are made for 1 competitor, namely BCA. From that goal value in Table 6, an improvement ratio (IR) can be determined according to Table 7, raw weight (RW) value as in Table 8 and normalized raw weight (NRW) values as in table 9.

Table 7

Improvement Ratio (IR) Value

\begin{tabular}{cccccccccccc}
\hline No & $5 \mathrm{c}$ & $4 \mathrm{c}$ & $5 \mathrm{~b}$ & $2 \mathrm{c}$ & $3 \mathrm{~b}$ & $4 \mathrm{a}$ & $1 \mathrm{~b}$ & $3 \mathrm{c}$ & $3 \mathrm{a}$ & $4 \mathrm{~b}$ & $5 \mathrm{a}$ \\
\hline $\begin{array}{c}\text { Improvement } \\
\text { ratio value }\end{array}$ & 1.26 & 1.25 & 1.25 & 1.24 & 1.26 & 1.24 & 1.18 & 1.24 & 1.24 & 1.22 & 1.24 \\
\hline
\end{tabular}

The IR value above shows the comparative value to make improvements to internet banking services. The IR value is obtained from the Goal Value in Table 7 divided by the level of customer satisfaction reflected by the CSP Value in table 6.

Table 8

Raw Weight (RW) Value

\begin{tabular}{ccccccccccccc}
\hline No & $5 \mathrm{c}$ & $4 \mathrm{c}$ & $5 \mathrm{~b}$ & $2 \mathrm{c}$ & $3 \mathrm{~b}$ & $4 \mathrm{a}$ & $1 \mathrm{~b}$ & $3 \mathrm{c}$ & $3 \mathrm{a}$ & $4 \mathrm{~b}$ & $5 \mathrm{a}$ \\
\hline $\begin{array}{c}\text { Raw weight } \\
\text { value }\end{array}$ & 4.964 & 4.925 & 4.850 & 4.873 & 4.851 & 4.762 & 4.685 & 4.749 & 4.749 & 4.673 & 4.700 & \\
\hline
\end{tabular}

RW value is obtained from the multiplication value between IR value in Table 7 and the value of customer importance level which is shown from IC value in Table 4.

Table 9

Normalize Raw Weight (NRW) Value

\begin{tabular}{|c|c|c|c|c|c|c|c|c|c|c|c|}
\hline No & $5 c$ & $4 c$ & $5 b$ & $2 \mathrm{c}$ & $3 \mathrm{~b}$ & $4 \mathrm{a}$ & $1 \mathrm{~b}$ & $3 c$ & $3 a$ & $4 \mathrm{~b}$ & $5 \mathrm{a}$ \\
\hline $\begin{array}{l}\text { Raw weight } \\
\text { value }\end{array}$ & 0.094 & 0.093 & 0.092 & 0.092 & 0.092 & 0.090 & 0.089 & 0.090 & 0.090 & 0.088 & 0.089 \\
\hline
\end{tabular}

NRW value in Table 9 is obtained by means of RW values in each attribute divided by the total value of all RW.

3) Technical response

It is a technical response from BRI as a service provider for emerging Voice of Customers. With this technical response, the problem solving in answering the voice of customer is found to be carried out and then the success rate is measured. Technical response is obtained from the results of discussions with stakeholders and decision making at BRI. The technical response based on the voice of customer in this study is summarized in Table 10.

Table 10

Technical Response Value

\begin{tabular}{llll}
\hline No & Technical Response & No & Technical Response \\
\hline 1 & Perform server maintenance & 6 & Perform network repair \\
2 & Improve the appearance of website pages & 7 & Increase bandwidth capacity \\
3 & Evaluate the process speed on each application feature & 8 & Added new online chat features \\
4 & Carry out enrollment of new internet banking features & 9 & Added new survey feature on web display \\
5 & Conduct regular website feature evaluations every quarter & 10 & Added video tutorials in Q \& A \\
\hline
\end{tabular}

\section{4) Relationship matrix}

Relationship matrix is the part of the roof of the HoQ that identifies the relationship between the voice of the customer and the technical response. Here it can be seen whether the technical responses support one another or interfere with one another in designing problem solving. The relationships used in this study are: 1) a strong positive relationship, that is, if one of the technical responses has increased or decreased, it will have a strong impact on the increase or decrease of other related items, 2) a moderate positive relationship, i.e. if one of the technical responses has increased or decreased, it will have a moderate 
impact on increasing or decreasing other related items, 3) low positive relationship, i.e. if one of the technical responses has increased or decreased, it will have a low impact on increasing or decreasing other related items. Relationship matrix can be seen in Fig. 4.

\section{5) Technical response}

Identifying whether there is interdependence between technical responses. Technical correlation can be seen in Fig. 4 .

6) Technical matrix

Technical matrix is the process of determining technical priorities that will be taken into consideration in the process of designing technical characteristics by calculating the weight value for each technical response. The weight value is obtained by multiplying the value that is in the relationship matrix with the normalized weight value for each consumer need.

Table 11

The priority of the plans

\begin{tabular}{llll}
\hline No & RW & NW & Priority \\
\hline 1 & 122 & 0,122 & 2 \\
2 & 63,6 & 0,063 & 8 \\
3 & 106 & 0,106 & 4 \\
4 & 109 & 0,109 & 3 \\
5 & 106 & 0,106 & 5 \\
6 & 106 & 0,106 & 6 \\
7 & 82,1 & 0,082 & 7 \\
8 & 132 & 0,132 & 1 \\
9 & 57 & 0,057 & 11 \\
10 & 61,4 & 0,061 & 9 \\
11 & 58,6 & 0,058 & 10 \\
\hline Total & 1003,7 & & \\
\hline
\end{tabular}

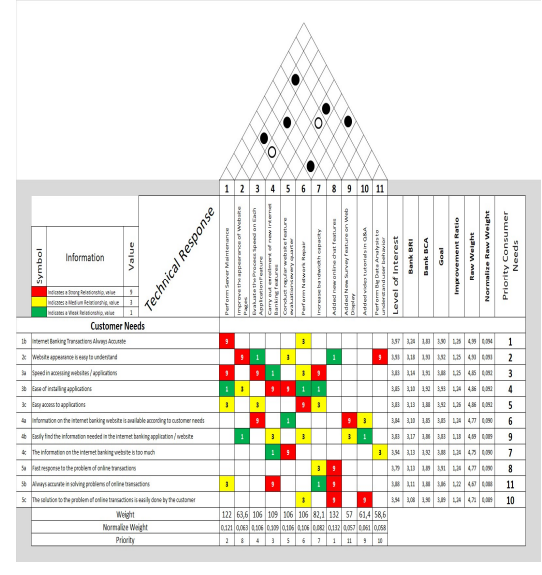

Fig. 4. House of Quality (HoQ

\section{Recommendation}

This recommendation is based on priority technical responses provided by the bank. The following recommendations can be given:

1) Adding new online chat features: The addition of this new feature is one of the solutions in the current era so that customers can directly interact with bank agents in solving their problems. The conversation was also developed to be able to include several links that connect with tutorial instructions, either in the form of e-books or videos.

2) Perform server maintenance: Server maintenance is conducted periodically to be able to maintain the performance of internet banking services so that the quality of services related to speed and ease of access can be maintained. In the long term, it is necessary to consider replacing the server hardware at least once every 10 years so that they are able to keep up with developments in IT technology.

3) Carry out enrollment of new internet banking features: New internet banking features that are in accordance with customer wishes need to be implemented so that the new menu can be in line with customer expectations. The ease in navigating this menu can improve customer perceptions of overall internet banking performance and speed. When customers easily use these new features, the customer's perception of internet banking speed will increase.

4) Evaluate the process speed of each application feature: Implementation of the process speed evaluation for each application feature needs to be done regularly. This is done to find bugs or create a shortcut to the process of each application's features. It is necessary to consider the possibility of process changes so as to increase speed for each internet banking application feature.

5) Conduct regular website feature evaluations every quarter: Website feature evaluation can be done periodically by utilizing the big data obtained from online chat features which allows customers to provide direct input to improve the website features, including the process of features, displays, and navigation menus on internet banking. In the next stage of development is a customize menu in the form of shortcuts or initial navigation on the website display to suit customer needs.

6) Perform network repair: The network is one of the determining factors in the quality of internet banking services, therefore an accurate calculation and review of the network used needs to be done. This of course is also related to network costs that need to be carefully considered. Analysis and evaluation to maintain the quality of service not only with a single layer backup, but also need to consider the concept of a double layer. 


\section{Conclusion}

Based on the results of analysis and data processing using the QFD method, it can be concluded that the level of quality of internet banking services at the Bank BRI Balikpapan Branch Office as a whole is still considered to be less good which can be judged by the average value of perceived customers lower than expected customers. Next, there are 11 priority variables to be fixed in Quadrant I in the Important Performance Analysis. From the results of data processing using QFD through the compilation of HoQ, the proposed improvements to improve the quality of Bank BRI Balikpapan Internet Banking services are the added of new online chat features, perform server maintenance, carry out enrollment of new internet banking features, evaluate the process speed of each application feature, conduct regular website feature evaluations every quarter and perform network repair.

\section{References}

Ariff, M. S. M., Yun, L. O., Zakuan, N., \& Jusoh, A. (2012). Examining dimensions of electronic service quality for internet banking services. Procedia-Social and Behavioral Sciences, 65(3), 854-859.

Bank, A. D. (2018). Embracing the E-commerce Revolution in Asia and the Pacific.

Brian Hwarng, H., \& Teo, C. (2001). Translating customers' voices into operations requirements-A QFD application in higher education. International Journal of Quality \& Reliability Management, 18(2), 195-226.

Besterfield, D. H., Bersterfield-michna, C. , Besterfield, G. H., \& Besterfield-sacre, M. (1999). Total Quality Management. Prentice Hall Inc.

Chan, L. K., \& Wu, M. L. (1998). Prioritizing the technical measures in quality function deployment. Quality engineering, 10(3), 467-479.

Cohen, L. (1995). Quality Function Deployment: How to Make QFD Work for You. Addison- Wesley, Reading, MA.

David, L., Goetsch, \& Davis, S. (2000). Quality management: introduction to total quality management for production, processing, and services. Prentice Hall.

DeYoung, R., Lang, W. W., \& Nolle, D. L. (2007). How the Internet affects output and performance at community banks. Journal of Banking \& Finance, 31(4), 1033-1060.

Herrmann, A., Huber, F., \& Braunstein, C. (2000). Market-driven product and service design: Bridging the gap between customer needs, quality management, and customer satisfaction. International Journal of production economics, 66(1), 77-96.

Hill, A. (1994). Quality function deployment. In: Lock, D. (Ed.), Gower Handbook of Quality Management, second ed. Gover, Brookfield, VT," 1994. [Online]. Available: https:/www.fose1.plymouth.ac.uk/sme/mst324/MST324-04 QFD.htm.

Carnevalli, J. A., \& Miguel, P. A. C. (2017). QFD aplication in different countries: a comparison of an exploratory study in Brazil with other surveys. Product: Management \& Development, 1(2), 5-18.

Ko, A. S. O., \& Lee, S. F. (2000). Implementing the strategic formulation framework for the banking industry of Hong Kong. Managerial Auditing Journal, 15(9), 469-477.

Lim, P. C., Tang, N. K. H., \& Jackson, P. M. (1999). Managing service quality: An innovative framework for health care performance measurement Innovation and strategy An innovative framework for health care performance measurement. Management Service Quality, 9(6), 423-433, 1999.

Şanlı, B., \& Hobikoğlu, E. (2015). Development of Internet banking as the innovative distribution channel and Turkey example. Procedia-Social and Behavioral Sciences, 195, 343-352.

Sullivan, L. P. (1986). Quality function deployment. Quality Progress, 39-50.

Stoica, O., Mehdian, S., \& Sargu, A. (2015). The impact of internet banking on the performance of Romanian banks: DEA and PCA approach. Procedia Economics and Finance, 20, 610-622.

Terninko, J. (1997). Step-by-Step QFD: Customer-Driven Product Design, second ed. St. Lucie Press, Boca Raton, FL.

Tan, K. C., \& Pawitra, T. A. (2001). Integrating SERVQUAL and Kano's model into QFD for service excellence development. Managing Service Quality: An International Journal, 11(6), 418-430.

Parasuraman, A., Zeithaml, V. A., \& Malhotra, A. (2005). ES-QUAL: a multiple-item scale for assessing electronic service quality. Journal of Service Research, 7(3), 213-233.

Yuan, X., Lee, H. S., \& Kim, S. Y. (1970). Present and future of internet banking in China. The Journal of Internet Banking and Commerce, 15(1), 1-10.

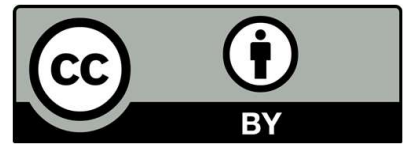

(C) 2020 by the authors; licensee Growing Science, Canada. This is an open access article distributed under the terms and conditions of the Creative Commons Attribution (CC-BY) license (http://creativecommons.org/licenses/by/4.0/). 